\title{
PARTICIPATIVE ANALYSIS OF SOCIO-ECOLOGICAL DYNAMICS AND INTERACTIONS. A CASE STUDY OF THE MANGLARALTO COASTAL AQUIFER, SANTA ELENA-ECUADOR
}

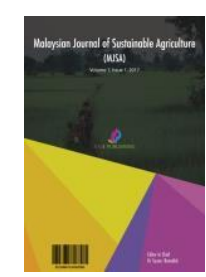

\section{G. Herrera-Franco ${ }^{a}$; T. Gavín-Quinchuelaab; N. Alvarado-Macancelaab; P. Carrión-Mero ${ }^{b}$}

a) Universidad Estatal Península de Santa Elena, UPSE, Facultad de Ciencias de la Ingeniería, Av. Principal Santa Elena-La Libertad, La Libertad, Ecuador.

b) ESPOL Polytechnic University, Escuela Superior Politécnica del Litoral, ESPOL, Centro de Investigación y Proyectos Aplicados a las Ciencias de la Tierra, CIPAT-ESPOL, Campus Gustavo Galindo Km. 30.5 Vía Perimetral, P.0. Box 09-01-5863, Guayaquil, Ecuador. Correspondence author: niucalva@espol.edu.ec

This is an open access article distributed under the Creative Commons Attribution License, which permits unrestricted use, distribution, and reproduction in any medium, provided the original work is properly cited

\section{ARTICLE DETAILS}

Articlehistory:

Received 12 May 2017

Accepted 18 May 2017

Available online 20 June 2017

Keywords:

Socio-ecological dynamics, coastal aquifer,

participatory method,

heritage.
ABSTRACT
Socio-ecological dynamics describe forms of interaction between society and ecosystems, through social, economic and ecological processes that influence the state of natural resources. The aim of this paper is to understand the functioning of the Manglaralto Socio-Ecological System through a participatory modeling method called PARDI (Problem, Actors, Resources, Dynamics and Interactions), in order to determine possible solutions for sustainability of groundwater resources. The sustainable management of the Manglaralto Coastal Aquifer has been identified as the problem. The actors involved in the socio-ecological dynamics of the Manglaralto Coastal Aquifer are the Manglaralto Regional Drinking Water Management Board as manager; as well as users, such as the population of rural communities and economic activities, highlighting the tourism activity. The key resources identified were rainfalls, forested areas and surface waters, which are considered the most relevant recharge sources of the coastal aquifer. The main dynamics and interactions that have directly intervened in the operation of the aquifer are: the growing water demand of 1,179.30\% during the period $2005-2015$ and the increase of $80.85 \%$ in the construction of urbanized areas for housing and tourist activities during the period 2006-2013. Currently, there are thirteen water wells; considered as the limit for the coastal aquifer. The Manglaralto Coastal Aquifer has dropped to $32.30 \%$ of its capacity, so there are schedules of water supply as a regulatory measure for the sustainability of the aquifer. Through in a participatory process between the actors involved, researchers and universities, possible collectively acceptable solutions have been identified for a first stage. These solutions are: the water repression through the construction of river tapes, the incentive for reforestation in livestock areas, a desalination plant and the nomination of the Manglaralto Coastal Aquifer as Heritage of Ecuador.

\section{INTRODUCTION}

Humans depend on biodiversity and ecosystems for the goods and services it provides, so biodiversity plays a very important role for human well-being and subsistence (Billé et al., 2012). Water is one of the main services provided by ecosystems (Mulligan et al., 2015); indispensable resource for the social and economic development of societies (Peña, 2016).

It is estimated that only $2.53 \%$ of the total water on the planet is fresh water and the rest is salt water. Surface water accounts for less than $3 \%$ of fresh water, the remaining $97 \%$ is found in groundwater (World Water Assessment Programme, 2003). By the year 2030, the world could face a water deficit of 40\% (2030 Water Resources Group, 2009); so the water scarcity is one of the main global environmental concerns (Hoekstra, 2016).

In most regions of the world the problem is not the lack of fresh drinking water, but the poor management and distribution of water resources (United Nations General Assembly, 2002). It is estimated that $20 \%$ of the world's aquifers are being overexploited, considering that there are 2.5 billion people who rely exclusively on groundwater resources in the world (Gleeson et al., 2012; United Nations World Water Assessment Programme, 2015).

23,586 inhabitants of the Manglaralto parish are supplied with groundwater from the Manglaralto coastal aquifer. The management of the Manglaralto coastal aquifer is in charge of the Manglaralto Regional Drinking Water Management Board (JAAPMAN, for its acronyms in Spanish) through the management of 13 water wells. The management of the coastal aquifer began in 1980 and currently the aquifer capacity has dropped by $32.30 \%$; this is due to several factors, being the most relevant the increase in the local and the tourism (Herrera et al., 2010; Herrera, 2016).
The objective of this article is to understand the socio-ecological dynamics of the Manglaralto coastal aquifer, through the participatory methodology called Problem-Actors-Resources-Dynamics and Interactions (PARDI) of Fallot (2013), in order to describe the interactions between ecosystems-society and to determine collectively acceptable solutions for the sustainability of the coastal aquifer.

\section{Materials and Methods}

The PARDI participatory methodology of Fallot (2013) is focused on improving the knowledge those actors have about the socio-ecological system in which they act, through the communication between the different actors and the exchange of points of view, in order to achieve a social and collaborative learning and to determine collectively acceptable solutions to problems of natural resources. This study is divided into three phases as shown in figure 1.

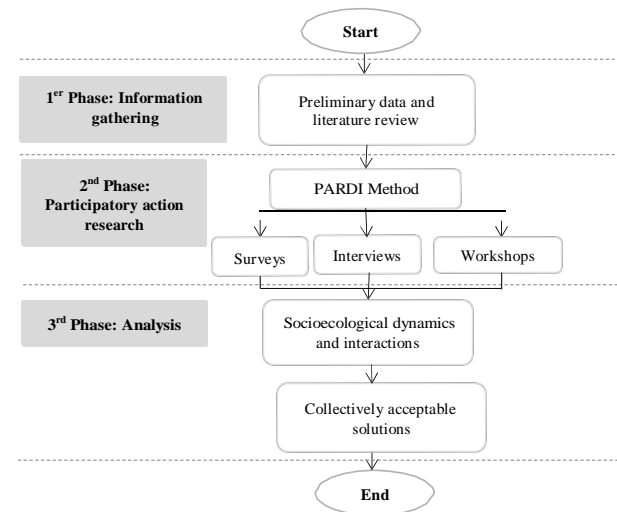

Figure 1. Phases of the study 
The 1st Phase is based on the collection of information through document analysis, being the basis of the study. The 2nd Phase is participatory action research through the PARDI method. This phase was developed from January to April 2017, through a participatory process among actors involved, such as the inhabitants of rural communities, JAAPMAN, parish representatives, researchers and universities as shown in figure 2; where 60 surveys, 8 interviews and 2 workshops were conducted.

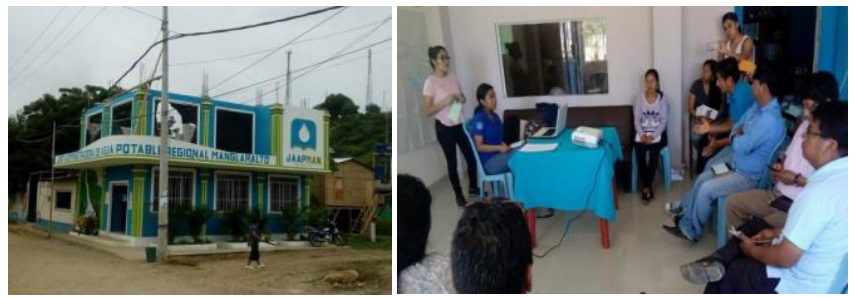

Figure 2. Participatory action research

The 3rd Phase is based on the analysis of the information, where the design of the socio-ecological dynamics and interactions of the Manglaralto coastal aquifer was made, through the integrated representation of the reality perceived by the actors involved. In addition, through this participatory modeling, collectively acceptable solutions were identified.

\section{Results and Discussion}

3.1 Brief description of study area

Manglaralto Parish is located in the province of Santa Elena in the Coasts of the Republic of Ecuador. It is constituted by the rural parish header called Manglaralto and 17 rural communities in an extension of $497.40 \mathrm{~km} 2$. Its population is 35,289 inhabitants until 2016 according to projections of the National Census. The main economic activities are tourism, retail trade, agriculture, livestock and fishing. The economically active population is $34.15 \%$; while poverty by unsatisfied basic needs is $88.20 \%$ (Instituto Nacional de Estadística y Censos, 2010)

There are three water boards in the parish: the Manglaralto Regional Drinking Water Management Board, created in 1980, the Olón Regional Drinking Water Management Board created in 1982, and the Valdivia Regional Drinking Water Management Board created in 1987. The Manglaralto Regional Drinking Water Management Board is in charge of managing the Manglaralto coastal aquifer and supplies water to a total of 23,586 inhabitants of the rural parish header and 5 rural communities such as: Montañita, Rio Chico, Cadeate, San Antonio and Libertador Bolívar (Herrera et al., 2017).

In 1980 started the exploitation of the Manglaralto Coastal Aquifer with a total of two water wells. During the period 2005-2011, seven new water wells were constructed. The Manglaralto coastal aquifer has worked at $100 \%$ capacity, providing water all hours in one day through pipes to homes. So community management of the coastal aquifer was recognized as a world example by the United Nations in 2011 (Macneill, 2011). During the period 2012-2014, four new water wells were constructed (Herrera, 2016).

Currently, there are thirteen water wells; considered as the limit for the coastal aquifer. The Manglaralto Coastal Aquifer has dropped to $32.30 \%$ of its capacity (Herrera, 2016), so there are schedules of water supply as a regulatory measure for the sustainability of the aquifer. In the dry season of Ecuador, when there is no rain, recharge of the aquifer is difficult. As a result, there have been demonstrations such as protests by villagers in rural communities over the lack of fresh water (Rosales, 2015; Cazar et al., 2016), because the JAAPMAN has been forced to close the keys that provide water through pipes to homes, so the water board have supplied water through water tanks in each house, limiting the amount of water for each household.

The Manglaralto basin has 13,238 ha of extension, while the coastal aquifer has an area of 508 ha (Herrera 2016). There are four wooded areas that directly influence the aquifer: Chongón-Colonche, Loma Alta, Cangrejal de Olón and Esterillo Oloncito, and six agricultural and livestock areas along the surface of the aquifer; such as: Dos Hermanos, Mar y Frío, Siempre Verde, Soledad María, El Refugio and Las Uvas, as shown in Figure 3.

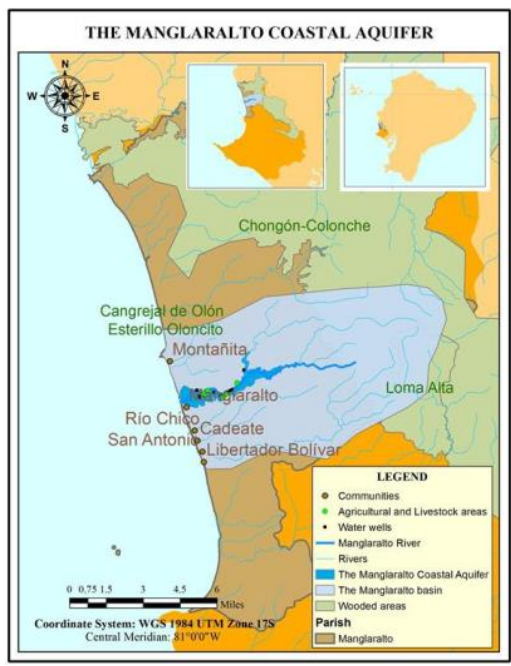

Figure 3. Environment of Manglaralto coastal aquifer

\subsection{Problem, Actors and Resources}

In the Manglaralto parish the problems of water scarcity are evident, mainly in the dry season (June-November), where there are no precipitations. So, during the dry season the recharge of aquifer is low. The problematic formulated based on the interests and needs of the actors involved in the subject of the sustainable management of the coastal aquifer in face of risks of scarcity, quality problems and the overexploitation poses the need to manage in a sustainable way the water of the Manglaralto coastal aquifer in a short (2 years), medium (9 years) and long term (20 years).

In the territory of Manglaralto six actors that affect the use of water resources and resources linked to water were identified. These actors intervene in the problem by their activities and functions, such as the JAAPMAN, communities, touristic and economic activities; as explained in table 1. Meanwhile, the main resources identified were precipitations, wooded areas, and rivers.

Table 1. Problem, Actors and Resources

How to sustainably manage the water of the Manglaralto coastal aquifer in a shor ( 2 years), medium ( 9 years) and long term ( 20 years)

- JAAPMAN: Autonomous community entity. It manages the Manglaralto coastal aquifer. The directive is composed by six members of the rural communities of the Manglaralto parish, democratically elected.

- Communities: 23.586 user

- Cominiticis

is one of the main sources of economic income for There therderly and unplanned growth of tourism has generated excessive demand for water.

Actors - Economic activities: Construction, livestock, agriculture, larvicultura, fishing, commerce, bakery.

- Comresentatives of the parish. Parish authorities, who are in charge of the planning a a the paris a

- Univerities: Researchers interested in solving problems of the communities in

order to improve the quality of life of the country.
Precipitations, wooded areas, rivers, construction of urbanized areas for housing and

Resources tourist activities on the banks of rivers, livestock and agricultural areas.

3.3 Dynamics and Interactions

The actors involved and researchers constructed through a participatory process a conceptual model focused on socio-ecological dynamics and interactions, as a tool to establish strategies for the sustainable management of the Manglaralto coastal aquifer. The main dynamics and interactions that have intervened directly in the operation of the aquifer have been the following:

- The growing water demand of $1,179.30 \%$ during the period 2005-2015. The aquifer is overexploited to meet the needs of water demand; this reduces the fresh water table and promotes saltwater intrusion into the coastal aquifer. The population has grown from 2,000 inhabitants in 2005 to 23,586 in 2015.

- The increase of $80.86 \%$ in the construction of urbanized areas for housing and tourist activities during the period 2006-2013. The increase of urbanized areas for housing and tourist activities on the banks of the river- Manglaralto aquifer system is a relevant factor in the sustainability of the coastal aquifer. By 2013 the expansion of urban areas was 196.39 ha; all communities underwent drastic changes in the coastal profile.

- The increase in tourist services, mainly the increase in accommodation by $1,775.00 \%$ during the period $2006-2014$. In 2006, there were 4 official hotel establishments located in the communities of Manglaralto. By 2014 there were 117 tourist businesses in the study communities according to the Ministerio de Turismo del Ecuador (2014), such as hostels, hotels, 
- restaurants and bars; of which 71 are hotels and hostels. In addition, it is known that in many cases there are accommodation services in housing of the inhabitants of the sector, because of the high demand of domestic and foreign tourists in the months of January to April and from July to September.

- The advance of the agricultural frontier has generated the felling of the humid forest located in the foothills of the ChongónColonche mountain range. Wooded areas have been reduced, so there is a shortage of rain and the level of water infiltration in the soil has decreased.

- Outstanding activities in the parish use water from the Manglaralto coastal aquifer. Baking is one of the main economic activities of the Cadeate community, with 48 businesses (bakeries) distributed in the commune of 2,000 inhabitants. The larviculture is another outstanding economic activity of the parish. There are five laboratories of shrimp and fish larviculture: Two in Cadeate, two in Manglaralto and one in Montañita.

- The results of the participatory process reflect the main effects that affect the recharge of the aquifer, which are: the scarce precipitations and the felling of the wooded areas for urbanizations or agricultural and/or livestock areas; which influence the drought of rivers and the lowering of groundwater level.

- The lack of regulation for the construction of urbanized areas on the banks of the river was identified. In addition, there was a lack of measures and policies that regulate the practices of activities that directly influence the exploitation of the coastal aquifer Manglaralto, considering that affect in the sustainability of the aquifer; such as the cementation of areas on and near to the coastal aquifer, which closes the entrance of rainwater to the deposit of groundwater.

Figure 4 shows the representation of the reality perceived by the actors involved, where the socio-ecological dynamics and interactions of the Manglaralto coastal aquifer resource can be observed.

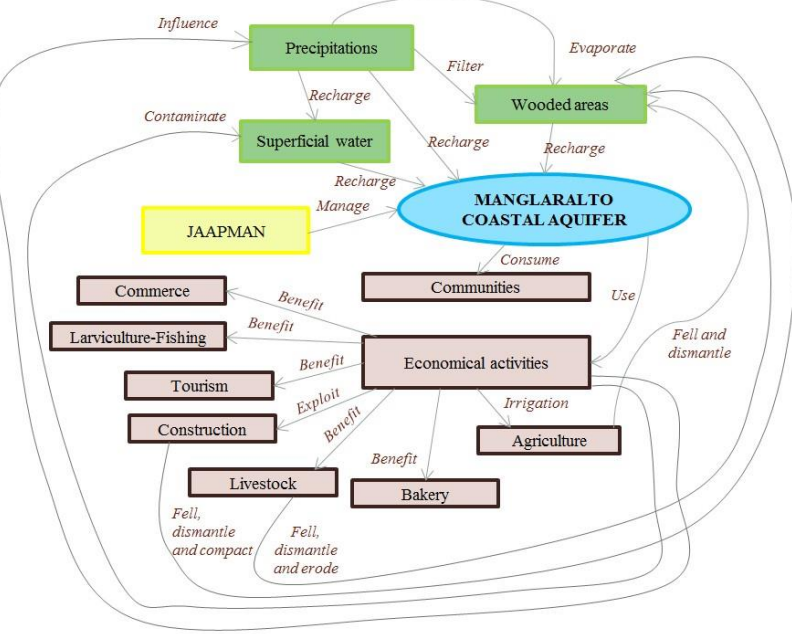

Figure 4. Socio-ecological dynamics and interactions of the Manglaralto coastal aquifer

\subsection{Collectively acceptable solutions}

Through the modeling of the socio-ecological dynamics and interactions of the Manglaralto coastal aquifer, collectively acceptable solutions were visualized in the short, medium and long term, as shown in figure 5.

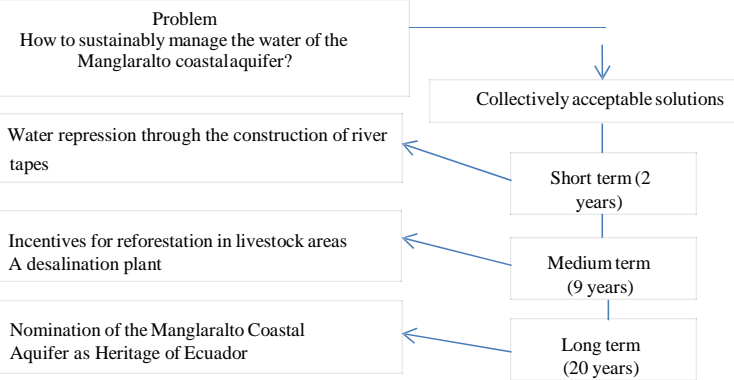

Figure 5. Collectively acceptable solutions for sustainability of the Manglaralto coastal aquifer

The construction of tapes for water repression is the earliest alternative according to participants in the participatory process. The tapes are structures similar to dykes, they are constructed perpendicular to the direction of the river channel, using backhoe loaders that transport the material of the channel of the river to block their course. In this way the water accumulates and facilitates the infiltration of the water for the recharge of the aquifer. The tapes should be prepared during the dry season between the months of July and October, being useful between February and April when the channel is full and its functionality is confirmed.

About 14,800 hectares of wooded areas in the Chongón-Colonche mountain range are conserved (Ministerio del Ambiente, 2015). Agricultural and livestock practices and the logging to take advantage of timber trees have reduced wooded areas. So the incentive of reforestation in livestock areas is important, because they have the most surface of territory of the parish. In addition, workshops with the local people are important to maintain and reforest the wooded areas; with the purpose of contributing to the mitigation of climate change and the maintenance of water resources and environmental services.

A desalination plant is another collectively acceptable solution. This alternative can mitigate water scarcity under extreme conditions. However, it is a process that is expensive and requires large amounts of energy. Therefore this possible solution is contemplated through alliances with the municipality and economic associations like the Association of Cattlemen and of Tourism. On the other hand, the nomination of the Manglaralto Coastal Aquifer as Heritage of Ecuador is envisaged in order to regulate and maintain the environmental services and water supply to rural communities through the National System of Protected Areas, Ecuadorian institution responsible for guaranteeing conservation of biodiversity and the maintenance of ecological functions that allow the sustainable use of natural resources

\section{Conclusion}

The analysis of the dynamics and interactions was carried out through the PARDI participatory modeling (Problem, Actors, Resources, Dynamics and Interactions) in order to understand the functioning of the Socio-Ecological System of Manglaralto around a shared problem such as the sustainability of the Manglaralto coastal aquifer. Actors involved, such as the local water board, inhabitants of rural communities, economic and tourist activities, parish representatives and researchers, made a conceptual model focused on socio-ecological dynamics and interactions through a participatory process; as a tool to establish collectively acceptable solutions for the sustainable management of the coastal aquifer in a short (2 years), medium (9 years) and long term (20 years).

The study has been a key to collectively identify the dynamics and interactions that affect the functioning of the aquifer. Uncertainties arise in the dynamics of resources, considering the low rainfall as a determining factor for the recharge of the aquifer. The interactions that have intervened in the overexploitation of the aquifer are the increasing water demand of 1,179.30\% during the period 2005-2015, the increase of $80.86 \%$ of urban areas during the period $2006-2013$, the increase in tourist accommodations by $1,775.00 \%$ during the period 2006-2014, the clearing of forested areas for urbanization or agricultural and/or livestock areas and the cementing of areas on and near to the coastal aquifer; so the aquifer has dropped to $32.30 \%$ of its capacity.

It is evident the need to coordinate actions and establish public policies that allow the regulation and use of space, in order to mitigate the negative impacts to the Manglaralto coastal aquifer; in other words, to avoid its disappearance, contamination, diminution of the quality and quantity of the water. In a process a participatory process between the involved actors were established possible solutions collectively acceptable for a first stage. These solutions are: the water repression through the construction of river tapes, the incentive for reforestation in livestock areas, a desalination plant and the nomination of the Manglaralto Coastal Aquifer as Heritage of Ecuador.

There are still several solutions to be discussed. This study is a first step in the long way for the sustainability of the Manglaralto Coastal Aquifer through a joint effort of stakeholders in the management of the resource. This is expected to be a starting point for the implementation of projects for aquifer valorization; considering that it 
is a resource with an important role in the social, economic, environmental and cultural development of the rural parish, and promotes the creation of a long-term integrity of natural resources and human well-being

\section{Acknowledgement}

Thanks to the rural communities of Montañita, Cadeate, Libertador Bolívar, Río Chico, San Antonio and the Manglaralto rural parish header for their active participation in surveys and workshops. To the representatives of the parish for their collaboration in the interviews and workshops, and a special thanks to the JAAPMAN for their unconditional support in the study.

\section{References}

[1] Davos-Klosters: Cougar Paper. 2030 Water Resources Group. (2009). Charting our water future: Economic frameworks to inform decision-making.

[2] Billé, R., Lapeyre, R., \& Pirard, R. (2012). Biodiversity conservation and poverty alleviation: a way out

of the deadlock? (I. V. Environnement, Ed.) S.A.P.I.EN.S Surveys and Perspectives Integrating Environment and, 5(1), 1-15.

[3] Cazar, D., Acuña, C., Ortiz, F., Orejuela, D., Madrid, A., \& Trujillo, J. (2016). Y la herencia cultural, ¿a quién le importa? Recuperado el 2017, de Revista Digital La Barra Espaciadora: http://www.labarraespaciadora.com/aqui-y-ahora/y-la-herenciacultural-a-quien-le-importa/

[4] Fallot, A. (2013). Guía metodológica PARDI - Problematica Actores - Recursos - Dinamicas - Interacciones: Para el análisis de las dinámicas socio-ecológicas. París: Archive Ouverte HAL.

[5] Gleeson, T., Wada, Y., Bierkens, M., \& van Beek, L. (2012). Water balance of global aquifers revealed by groundwater footprint. Nature, 197-200.

[6] Herrera, G. (2016). Estudio para un Modelo de Gestión de un Acuífero Costero, mediante Metodologías Participativas y Análisis Geoestadístico en el marco del Desarrollo Local. Manglaralto, Ecuador. Departamento de Ingeniería Topográfica y Cartografía. Madrid: Universidad Politécnica de Madrid.

[7] Herrera, G., Carrión, P., Berrezueta , E., \& Flores, D. (2010). Valoración de Impactos Ambientales Relacionados con las Aguas Subterráneas y Turismo en las Comunas de Manglaralto y Olón; Ecuador. En Técnicas Aplicadas a la Caracterización y Aprovechamiento de recursos Geológico-Mineros. (págs. 116-126). Oviedo: Instituto Geológico y Minero de España.

[8] Herrera, G., Carrión, P., \& Alvarado-Macancela, N. (2017). Participatory process for local development: Sustainability of water resources in rural communities. Case Manglaralto-Santa Elena, Ecuador. En Handbook of Sustainability Science and Research. Springer.

[9] Hoekstra, A. Y. (2016). A critique on the water-scarcity weighted water footprint in LCA. (J. Marques, \& F. Müller, Edits.) Ecological Indicators, 66, 564-573. http://dx.doi.org/10.1016/ j.ecolind.2016.02.026.

[10] Instituto Nacional de Estadística y Censos. (2010). Sistema Integrado de Consultas. (D. d. Centro Latinoamericano y Caribeño de Demografía (CELADE), Editor) Recuperado el 22 de August de 2016, de VII Censo de Población y VI de Vivienda: http:// redatam.inec.gob.ec/

[11] Macneill, M. (2011). IAEA Helps Parched Santa Elena Find Water. Recuperado el 2017, de International Atomic Energy Agency : https://www.iaea.org/newscenter/news/iaea-helps-parched-santaelena-find-water

[12] Ministerio de Turismo del Ecuador. (2014). Catastro Turístico de la Provincia de Santa Elena. Santa Elena: República del Ecuador.

[13] Ministerio del Ambiente. (2015). Beneficiarios de Socio Bosque se capacitan en Santa Elena. Recuperado el 2017, de Programa de Protección de Bosques Socio Bosque: http://sociobosque.ambiente.gob.ec/node/682
[14] Mulligan, M., Benítez-Ponce, S., Lozano-V., J., \& Leon Sarmiento, J. (2015). Policy support systems for the development of benefit-sharing mechanisms for water-related ecosystem services. En J. Martin-Ortega, R. Ferrier, I. Gordon, \& S. Khan, Water Ecosystem Services. A Global Perspective (págs. 99-109). Cambridge: International Hydrology Series and Cambridge University Press.

[15] Peña, H. (2016). Desafíos de la seguridad hídrica en América Latina y el Caribe. (Comisión Económica para América Latina y El Caribe-CEPAL, Ed.) Serie Recursos Naturales e Infraestructura(178), 1-57.

[16] Rosales, E. (2015). Problemas en Manglaralto. Recuperado el 2017, de Diario El Universo: http://www.eluniverso.com/ opinion/2015/10/19/nota/5192870/problemas-manglaralto

[17] United Nations General Assembly. (2002). Report of the World Summit on Sustainable Development (WSSD). Johannesburg: United Nations.

[18] United Nations World Water Assessment Programme. (2015). The United Nations World Water Development Report 2015: Water for a Sustainable World. Paris: UNESCO.

[19] World Water Assessment Programme. (2003). Water for People, Water for Life. The United Nations World Water Development Report. Paris: United Nations.

\section{About the Authors}

Professor Gricelda Herrera Franco has a doctorate in Geographic Engineering (2016). She is professor and researcher at Universidad Estatal de la Península de Santa Elena (UPSE, for its acronyms in Spanish) in Ecuador. Her current research interests include geography, participative methodologies, territorial and local development

Researcher Tatiana Gavín Quinchuela has a degree in Ecotourism (2013). She is researcher at Center for Research and Projects applied to Earth Sciences at Escuela Superior Politécnica del Litoral (CIPATESPOL, for its acronyms in Spanish) in Ecuador. Her current research interests include environmental sciences and sustainability.

Researcher Niurka Alvarado Macancela has a degree in International Business (2015). She is researcher of the area of Project Economics and Technology Transfer at CIPAT-ESPOL and of Ancón-Santa Elena Geopark Research Project at UPSE in Ecuador. Her current research interests include development and geopark.

Professor Paúl Carrión Mero has a doctorate in Mining Engineering (2005). He is professor at Escuela Superior Politécnica del Litoral and Director of CIPAT-ESPOL in Ecuador. His current research interests include earth sciences, environmental sciences and sustainability. 